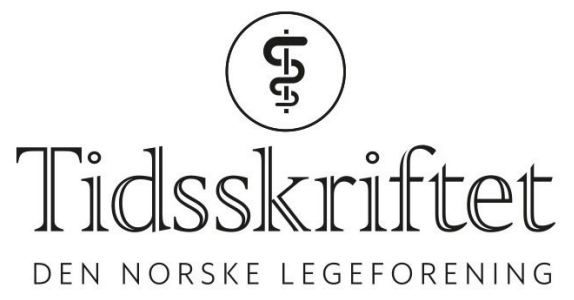

\title{
Utdanning gir lavere risiko for hjertesykdom
}

FRA ANDRE TIDSSKRIFTER

KETIL SLAGSTAD

Tidsskriftet

Høy utdanning er assosiert med redusert risiko for hjerte- og karsykdommer. En ny studie styrker teorien om at sammenhengen er kausal.

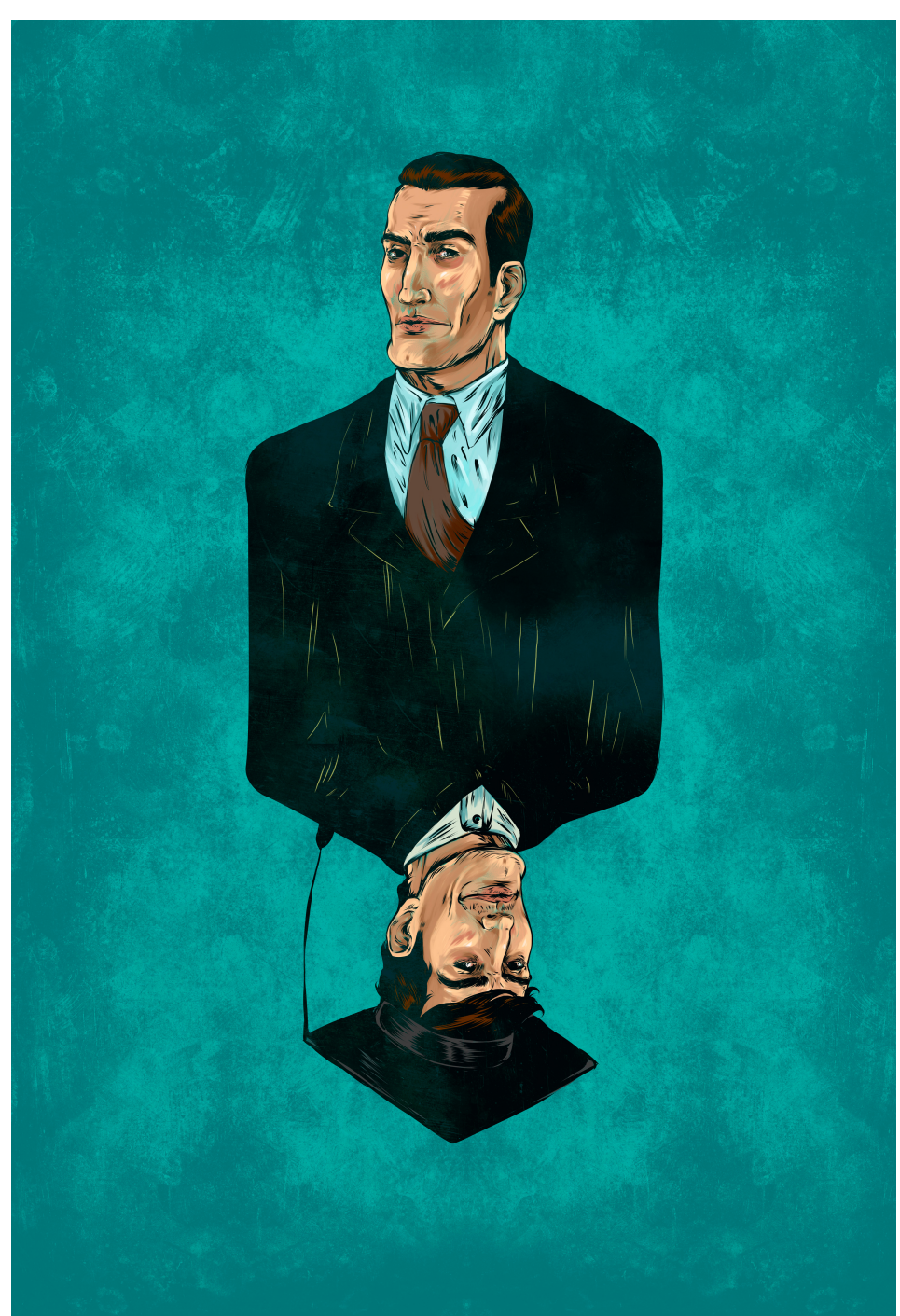

Illustrasjonsfoto: Science Photo Library 
Sosioøkonomisk status henger sammen med risikoen for hjerte- og karsykdom. Mange studier har vist at mennesker med høy utdanning har lavere risiko for slik sykdom enn folk med mindre skolegang, men det er usikkert om sammenhengen er kausal, ettersom det ikke er mulig å gjennomføre randomiserte, kontrollerte studier. Ved bruk av såkalt mendelsk randomisering benyttes genvarianter som er assosiert med en risikofaktor, for eksempel utdanning, for å komme nærmere forståelsen av sammenhengen mellom risikofaktor og sykdom. Metoden er blitt beskrevet som «naturens randomiserte, kontrollerte forsøk».

I en studie som nylig er publisert i tidsskriftet $B M J$, ble data om enkeltnukleotidpolymorfismer som er assosiert med utdanningsnivå, hentet fra genomvide assosiasjonsstudier (genom-wide association studies, GWAS) og sammenlignet med funn fra tradisjonelle observasjonelle studier (1). Studien bekrefter at genetisk predisposisjon for høyere utdanning reduserer risikoen for koronarsykdom - i gruppen med 3,6 år lenger utdanning enn i den andre gruppen var risikoen for slik sykdom ca. 30 \% lavere (oddsratio o,67, $95 \%$ KI o,59-0,77).

- Personer med høyere utdanning har lavere risiko for hjerte- og karsykdom, men det har vært vanskelig å fortolke sammenhengen, sier Per Magnus, som er fagdirektør ved Folkehelseinstituttet. - I denne studien har man brukt gener som instrumentvariabler for å avklare nærmere om det er en årsakssammenheng. Instrumentvariabler er faktorer som henger sammen med eksponeringen (utdanningen), men ikke med utfallet (sykdommen) gjennom andre mekanismer. Denne forutsetningen er vanskelig å teste for gener. Et gen kan være pleiotropt, det vil si at det kan påvirke mer enn én fenotype. I denne studien brukes nye teknikker for å avklare pleiotropi, og resultatene styrker en forståelse av at utdanning er årsaksmessig forbundet med hjerte- og karsykdom, selv om de ikke sier så mye om hvilke mekanismer utdanning virker gjennom, sier Magnus.

\section{LITTERATUR:}

1. Tillmann T, Vaucher J, Okbay A et al. Education and coronary heart disease: mendelian randomisation study. BMJ 2017; 358: j3542. [PubMed][CrossRef]

Publisert:30. oktober 2017. Tidsskr Nor Legeforen. DOI: 10.4045/tidsskr.17.0803

(C) Tidsskrift for Den norske legeforening 2020. Lastet ned fra tidsskriftet.no 